\title{
Pelatihan Penggunaan Aplikasi Sparkol VideoScribe Sebagai Media Pembuatan Video Pembelajaran Berbasis Digital di SMP Muhammadiyah Pangsid
}

\author{
Jumiati, Nurmayanti, Aswadi, Suleha, Nurlaelah, Zulkipli, Syukriah Musagani
}

\begin{abstract}
Latar Belakang
Perkembangan teknologi informasi dan telekomunikasi di bidang pendidikan ditandai dengan pelaksanaan proses pembelajaran berbasis digital. Pada masa pandemi, pembelajaran berbasis digital semakin diperhitungkan dalam pelaksanaan pembelajaran, terlebih proses belajar mengajar harus dilakukan dari rumah dan siswa diarahkan untuk belajar mandiri. Guru sebaiknya mampu mendesain bahan ajar sedemikian rupa agar siswa dapat melakukan proses belajar mandiri dan meningkatkan minat belajarnya. Aplikasi Sparkol VideoScribe merupakan salah satu media yang dapat digunakan dalam mendesain bahan ajar yang menarik, terutama dalam bentuk video pembelajaran.
\end{abstract}

Permasalahan

Guru belum mampu membuat materi ajar berbasis video pembelajaran

Lokasi Pengabdian

SMP Muhammadiyah Pangsid

Solusi

Melakukan pelatihan kepada guru dalam membuat video pembelajaran berbasis digital menggunakan aplikasi Sparkol VideoSribe

Waktu Pelaksanaan

19 September 2020

Metode

Metode yang digunakan dalam pelatihan ini adalah sebagai berikut:

1. Menentukan pelatihan pembuatan Video Pembelajaran menggunakan aplikasi Sparkol VideoScribe

2. Memaparkan deskripsi singkat aplikasi Sparkol VideoScribe dalam pembuatan video pembelajaran

3. Memaparkan tutorial penggunaan tools pada aplikasi Sparkol VideoScribe

4. Melatih guru dalam membuat video pembelajaran menggunakan aplikasi Sparkol VideoScribe

Luaran

Pelatihan pembuatan video pembelajaran bagi guru menggunakan aplikasi Sparkol VideoScribe

Kesimpulan

Melalui pelatihan penggunaan aplikasi Sparkol VideoScribe, guru dapat membuat video pembelajaran berbasis digital . 
Rujukan pelaksanaan kegiatan yakni Aswadi (2015, 2018, 2017); (Anggita et al., 2016; Rasyid \& Aswadi, 2020a, 2020b); (Andarwulan \& Aswadi, 2017; Damayanti et al., 2019)

Daftar Pustaka

Andarwulan, T., \& Aswadi, A. (2017). Menilik Sikap Bahasa Mahasiswa Universitas Brawijaya: Upaya Peneguhan Bahasa Indonesia Menuju Internasionalisasi Bahasa. WASKITA: Jurnal Pendidikan Nilai Dan Pembangunan Karakter, 2(2), 61-70.

https://doi.org/10.21776/ub.waskita:jurnalpendidikannilaidanpembangunankarakter.2018.002 .02 .6

Anggita, N., Rasyid, R. E., \& Aswadi. (2016). Pengaruh Metode Role Playing Terhadap Pembelajaran Drama. 5151(2), 908-914.

Aswadi. (2015). Kesalahan Gramatikal pada Karangan Narasi Mahasiswa STKIP Muhammadiyah Sidenreng Rappang. Panrita, 10(10), 106-114.

Aswadi. (2018). Mengulik Akar Kritis dalam Analisis Wacana Kritis dan Implementasinya Terhadap Teks Berita. Lensa: Kajian Kebahasaan, Kesusastraan, Dan Budaya, 8(2), 176-188. https://jurnal.unimus.ac.id/index.php/lensa/article/download/3214/pdf

Aswadi. (2017). Pembelajaran Keterampilan Menyimak Kritis sebagai Sarana Pemerolehan Pengetahuan. Seminar Internasional Riksa Bahasa XI, 1(Pps Universitan Pendidikan Indonesia), 911.

Damayanti, G., Andarwulan, T., \& Aswadi, A. (2019). Mekanisme Eufemisme Dan Sensorisasi: Kekerasan Simbolik Dalam Tuturan Dosen. RETORIKA: Jurnal Bahasa, Sastra, Dan Pengajarannya, 12(2), 223. https://doi.org/10.26858/retorika.v12i2.9101

Rasyid, R. E., \& Aswadi. (2020a). Penerapan Metode Lekat dalam Pembelajaran Menulis Puisi. Nene Mallomo IGI Sidrap, 1(1), 51-55.

Rasyid, R. E., \& Aswadi, A. (2020b). Efektivitas Program Belajar Dari Rumah (BDR) Model Daring dalam Masa Pandemi Covid-19. KONFERENSI NASIONAL ILMU KOMPUTER KE 4 KONIK 2020 EDISI COVID-19, 659-662. 
Pelatihan Penggunaan Aplikasi Sparkol VideoSeribe Sebagai Media Pembuatan Video Pembelajaran Berbasis Digital di SMP Muhammadiyah Pangsid

Oleh :

Jumiati, Nurmayanti, Aswadi, Suleha, Nurlaelah, Zulkifli N, Syukriyah Musagani

\section{Latar Belakang}

Perkembangan teknologi informasi dan telekomunikasi di bidang pendidikan ditandai dengan pelaksanaan proses pembelajaran berbasis digital. Pada masa pandemi, pembelajaran berbasis digital semakin diperhitungkan dalam pelaksanaan pembelajaran, terlebih proses belajar mengajar harus dilakukan dari rumah dan siswa diarahkan untuk belajar mandiri. Guru sebaiknya mampu mendesain bahan ajar sedemikian rupa agar siswa dapat melakukan proses belajar mandiri dan meningkatkan minat belajarnya. Aplikasi Sparkol VideoScribe merupakan salah satu media yang dapat digunakan dalam mendesain bahan ajar yang menarik, terutama dalam bentuk video pembelajaran.

\section{Permasalahan}

Guru belum mampu membuat materi ajar berbasis video pembelajaran

\section{Lokasi Pengabdian}

SMP Muhammadiyah Pangsid

\section{Waktu Pelaksanaan}

19 September 2020

\section{Solusi}

Melakukan pelatihan kepada guru dalam membuatv video pembelajaran berbasis digital menggunakan aplikasi Sparkol VideoSribe
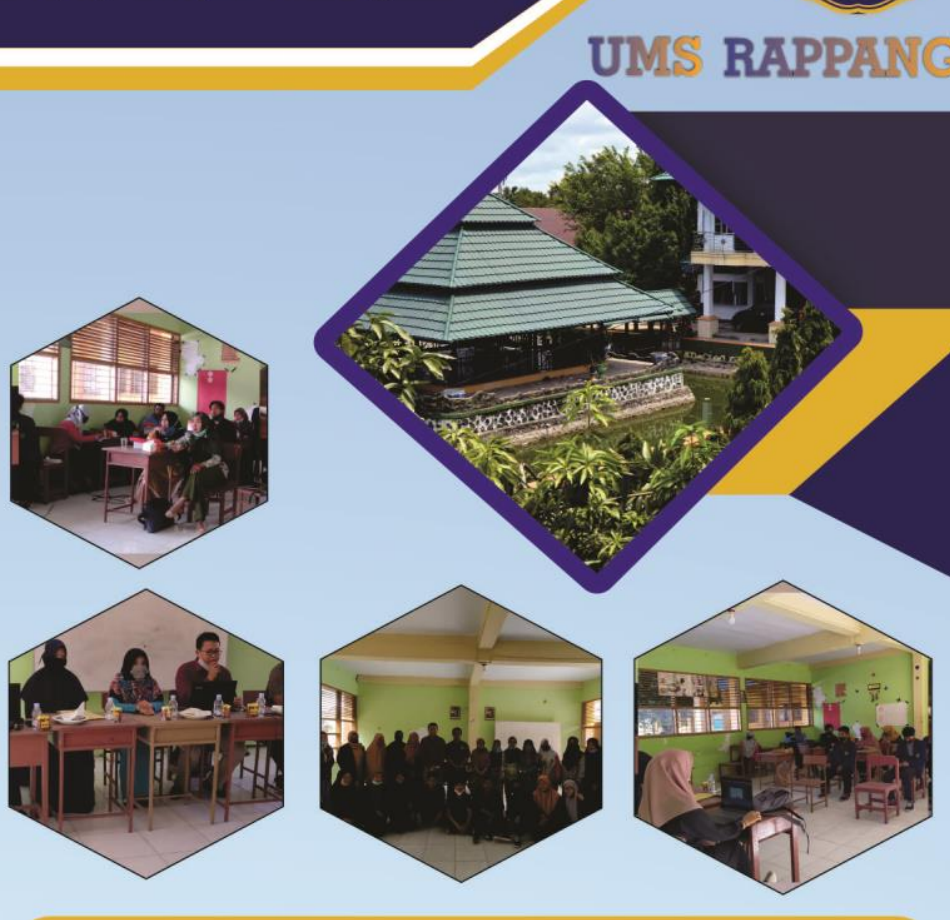

\section{Metode}

Metode yang digunakan dalam pelatihan ini adalah sebagai berikut:

Menentukan pelatihan pembuatan Video Pembelajaran menggunakan aplikasi Sparkol VideoScribe

Memaparkan deskripsi singkat aplikasi Sparkol VideoScribe dalam pembuatan video pembelajaran

Memaparkan tutorial penggunaan tools pada aplikasi Sparkol VideoScribe Melatih guru dalam membuat video pembelajaran menggunakan aplikasi Sparkol VideoScribe

\section{Luaran}

Pelatihan pembuatan video pembelajaran bagi guru menggunakan aplikasi Sparkol VideoScribe

\section{Kesimpulan}

Melalui pelatihan penggunaan aplikasi Sparkol Video Scribe, guru dapat membuat video pembelajaran berbasis digital .

\section{Universitas Muhammadiyah Rappang}

